\title{
EFFECT OF SOME ADMIXTURES ON HEAT OF HYDRATION REACTION OF CEMENT PASTES PRODUCED IN YEMEN, SAUDI ARABIA, AND EGYPT.
}

\author{
Fatima A. Al-Qadri ${ }^{a}$, A. M. Saad ${ }^{b}$, Affaf Ahmed Aldlaee $^{c}$ \\ ${ }^{a}$ Associate Professor, Department of Chemistry, University of Sana'a Yemen. \\ ${ }^{b}$ Associate Professor, Department of Chemistry, University of Sana'a, Yemen. \\ ${ }^{c}$ Graduated student, Department of Chemistry, University of Sana'a, Yemen.
}

(Received July 12, 2009 Accepted July 27, 2009)

\begin{abstract}
Blended cement pastes were prepared with and without silica fume and fly ash using an initial water/cement ratio of 0.40. Effect of these two mineral admixtures (silica fume, and fly ash) on the heat evolution of hydration reactions of Portland cement produced in Yemen, Egypt and Saudi Arabia has been studied at various hydration times. The heat of hydration of OPC in the presence of admixtures was studied, by using calorimetric method. The results show that the heat of hydration of Portland cement is retarded in the presence of both the admixtures.
\end{abstract}

KEY WORDS: Portland cement, heat of hydration, silica fume, fly ash.

\section{1- INTRODUCTION}

Portland cement is a multi component system. The main factors that affect the Rate of cement hydration are cement composition, cement fineness, water-to-cement ratio, curing time, and curing temperature when ordinary Portland cement (opc) is mixed with water; a series of chemical reactions begins to take place. The reactions of cement with water proceed at different rates for the various mineral phases and involve both hydrolysis and hydration processes [1]. Raw materials of cement: Limestone, argillaceous, shales, chalks, schists, shells clays, calcerous muds, other iron-bearing alumino- silicates and additional iron may be required as a fluxing aid [2].

Super plastizers are now widely used in the production of concrete with excellent workability, for easy placement with out reduction in cement content and strength. These admixtures are extremely effective for dispersing cement particles in water. The dispersion mechanism has been described in terms of electrostatic repulsive forces between the cement particles followed by adsorption of charged superplastizer molecules. Several reports have been concerned with the improvement of the strength and development of Portland cement using admixtures [3-5]. Superplastizers have been used to reduce the water of consistency and to improve the workability of cement pastes and consequently concrete, leading to improvement in mechanical. Properties and resistance towards environmental deterioration, chemical attack and pastes at early stages.

Fly ash from coal-fired thermal power stations, granulated blast furnace slag from steel industries and silica fume from Ferro-silicon alloys or silicon metal industries are prominently used as additives to cement and concrete the world over, for making concrete more durable. Such combinations are the ideal cement systems for durable Concrete [6]. Silica fume is a byproduct of producing silicon metal or 
ferrosilicon alloys. Silicon metal and alloys are produced in electric furnaces. The raw materials are quartz, coal, and woodchips. The smoke that results from furnace operation is collected and sold as silica fume, rather than being land filled. Silica fume consists primarily of amorphous (non-crystalline) silicon dioxide ( $\mathrm{SiO} 2)$, its average granule diameter is $0.15 \sim 0.20 \mu \mathrm{m}$, and it has extremely strong surface active. Because of its fine particles, large surface area, and the high $\mathrm{SiO} 2$ content, silica fume is a very reactive pozzolan when used in concrete. At the same time, silica fume can still be used in the production of refractory and porcelain; to raise intensity and durability .It also can improve the material overall performance as filler, used in paint, coating, resin, rubber and other high molecular material [7].

At early ages, hydration of concrete is characterized by an important heat release due to the exothermic character of hydration reactions. This heat release causes deformations of the material and can create cracks and micro-cracks in large concrete structures. Such cracking can lead to a loss of durability for concrete structures. In order to predict those thermally-induced deformations and avoid cracking, it is important to clearly define the thermal behavior evolution of the reactive component of concrete, in other words: cement paste. This study deals with the evolution of thermophysical properties (thermal conductivity and specific heat) of cement paste.[8].When cement and water are mixed together, the reactions, which occur, are mostly exothermic - heat is produced. We can get an indication of the rate at which the minerals are reacting by monitoring the rate at which heat is evolved using a technique called conduction calorimetry [9].The ability to accurately quantify the water to cement ratio and degree of hydration in the cement paste is an important benefit in characterizing strength and service life of concrete structures [10].In the present paper, fly ash and silica fume were used as additives to the blended cement pastes made with an initial water/cement (w/c) ratio of 0.40 by weight as Reported [11]. The effect of this admixture on the heat of hydration of hardened cement pastes was clarified.

\section{2- EXPERIMENTAL}

\section{2-1 Materials}

The Cements are all manufactured in Yemen, Egypt, and Saudi, The oxide composition of the cements and their surface areas are shown in Table 1, and Table 2 respectively, according to the manufacturer.

Table 1: The oxide composition of the Cements

\begin{tabular}{|c|c|c|c|c|c|c|c|}
\hline Oxides & $\mathrm{CaO}$ & $\mathrm{SiO}_{2}$ & $\mathrm{Al}_{2} \mathrm{O}_{3}$ & $\mathrm{Fe}_{2} \mathrm{O}_{3}$ & $\mathrm{MgO}$ & $\mathrm{SO}_{3}$ & Ign.loss \\
\hline Saudi cement & 64.19 & 22.59 & 4.61 & 2.71 & - & 2.22 & 1.48 \\
Yemen cement & 61.96 & 21.33 & 5.20 & 3.05 & 2.11 & 1.96 & 1.48 \\
Egypt cement & 64.0 & 21.06 & 5.43 & 3.41 & 0.75 & 2.48 & 2.42 \\
Fly ash & 5.60 & 55.30 & 25.70 & 5.30 & 2.10 & 1.40 & 0.90 \\
Silica fume & 0.30 & 94.3 & 0.09 & 0.10 & 0.43 & 0.10 & 1.14 \\
\hline
\end{tabular}


Table 2 : Blaine area of different Portland cement.

\begin{tabular}{|c|c|}
\hline Type of cement & $\begin{array}{c}\text { Surface area } \\
\text { am } / \mathrm{s}\end{array}$ \\
\hline Yemen cement & $3100 \mathrm{~cm}^{2} / \mathrm{gm}$ \\
\hline Saudi cement & $2777 \mathrm{~cm}^{2} / \mathrm{gm}$ \\
\hline Egypt cement & $3000 \mathrm{~cm}^{2} / \mathrm{gm}$ \\
\hline Fly ash & $2900 \mathrm{~cm}^{2} / \mathrm{gm}$ \\
\hline Silica fume & $2774 \mathrm{~cm}^{2} / \mathrm{gm}$ \\
\hline
\end{tabular}

\section{2-2 Experimental instrument:}

\section{2-2A Existing Test Methods:}

Cement hydration is an exothermal process. The measurement of the heat is a convenient way to monitor and quantify the hydration reaction. There four major types of calorimeters used in cement science and technology: adiabatic calorimeters, semiadiabatic calorimeters, isothermal calorimeters, and solution calorimeters. Expect for these four major types of calorimeters, other methods are developed to monitor the heat generation process.

The isothermal calorimeter used is the 3114/3326, TAM Air isothermal calorimeter. It is an eight -channel calorimeter operating in the miliwatt region. The capacity chosen in this research was $600 \mathrm{~mW}$. The calorimeter is located in room temperature was set to $20^{\circ} \mathrm{C}$. At measurement temperatures, higher than the environment temperature, in order to prevent as much as thermal shock to the calorimeter due to the temperature difference between the sample and calorimeter, both cement and water are kept in the oven till the desired mixing temperature before mixing and isothermal measurement.

\section{2-2b Experimental Method}

Cement pastes were prepared by adding mineral admixtures, which were fly ash and silica fume with different ratios. Table 3 summarizes the mixture proportions of the three investigated binder pastes. The water cementations materials ratio was kept constant at 0.40 .

\section{2-2c Heat Evolution Measurements}

The heats of hydration of OPC in the absence and presence of $3.0 \mathrm{wt}$. (\%) fly ash and 3.0 wt. (\%) silica fume were determined with the help of 8 probe TAM AIR calorimeter at $20{ }^{\circ} \mathrm{C}$ in a way similar to that described in the above [12]. The watersolid ratio was kept to be 0.4 , the prepared mixtures of cement pastes were taken in glass vials and were shaken for one minute in order to have homogeneous mixing and then kept in a calorimeter at $20^{\circ} \mathrm{C}$. The heat flow as a function of time was recorded using quartz powder as a reference. 
Table 3: Mixture of proportions of cement pastes.

\begin{tabular}{|c|c|c|c|c|}
\hline $\begin{array}{c}\text { Type of } \\
\text { cement }\end{array}$ & $\begin{array}{c}\text { Designation } \\
\text { of cement } \\
\text { pastes }\end{array}$ & $\begin{array}{c}\text { Silica fume } \\
\text { content } \%\end{array}$ & $\begin{array}{c}\text { Fly ash } \\
\text { content\% }\end{array}$ & $\begin{array}{c}\text { W/C } \\
\text { Water cement } \\
\text { ratio }\end{array}$ \\
\hline Yemen & $\mathrm{Ye}$ & - & - & 0.4 \\
\hline Saudi & $\mathrm{Sa}$ & - & - & 0.4 \\
\hline Egypt & $\mathrm{Eg}$ & - & - & 0.4 \\
\hline Yemen & $\mathrm{YeSi}$ & 3 & - & 0.4 \\
\hline Saudi & $\mathrm{SaSi}$ & 3 & - & 0.4 \\
\hline Egypt & $\mathrm{EgSi}$ & 3 & - & 0.4 \\
\hline Yemen & $\mathrm{YeF}$ & - & 3 & 0.4 \\
\hline Saudi & $\mathrm{SaF}$ & - & 3 & 0.4 \\
\hline Egypt & $\mathrm{EgF}$ & - & 3 & 0.4 \\
\hline
\end{tabular}

\section{3- RESULTS AND DISCUSSION}

The heat flow as a function of time during the hydration of cement in the absence and presence of $3.0 \mathrm{wt}(\%)$ fly ash and silica fume are shown in Figures 1,2and 3. In the case of reference, the curve is divided into five parts:

1) Rapid heat evolution due to cement wetting, dissolution of alkalis, dissolution of hemihydrates and hydration of $\mathrm{C}_{3} \mathrm{~A}$ and its reaction with gypsum.

2) Induction period where the hydration products acquire certain critical size.

3) As soon as the critical size is reached, the nucleation and crystal growth starts, hydration accelerates with time and reaches to a maximum value. In this stage mainly the hydration of alite phase occurs.

One of the hydration products is C-S-H, which may be of nanometer size.

4) Deceleration period where the rate of heat evolution decreases with hydration time due to the formation of large amount of hydration products and,

5) The last stage in which the rate of reaction is very slow and the reaction is diffusion controlled.

Mineral admixtures, such as fly ash and silica fume, can significantly reduce the rate and amount of heat development, $3.0 \mathrm{wt}$. (\%) fly ash and silica fume modify different stages of rate of heat evolution, for fly ash Various researchers have studied the effect of fly ash on cement hydration [13] determined that adding a low-calcium fly ash reduces the heat of hydration of cement. Some high-calcium Class $\mathrm{C}$ fly ash with self-cementitious properties may react very quickly with water, releasing excessive heat just like normal OPC hydration [14]. The total heat of hydration of fly ash normally depends on the content of

$\mathrm{CaO}[15]$ fly ash not only decreases the maximum heat generation rate but also postpones the peak of hydration. As the fly ash ratio increases, the peak becomes wider. Figures 1, 2, and 3 shows that the retardation of cement hydration mainly occurs during the dormant and acceleration periods. When cement-fly ash cement mixes with 
water, the $\mathrm{Ca}^{2+}$ ion in pure solution is removed by the fly ash, which reacts like a $\mathrm{Ca}$ sink. The depressed $\mathrm{Ca}^{2+}$ concentration delays the nucleation and crystallization of $\mathrm{CH}$ and $\mathrm{C}-\mathrm{S}-\mathrm{H}$, retarding hydration. The depressed $\mathrm{Ca}^{2+}$ concentration delays the nucleation and crystallization of $\mathrm{CH}$ and $\mathrm{C}-\mathrm{S}-\mathrm{H}$, retarding hydrate [16].The results show that for the same concentration, fly ash is a better retarder than silica fume.

\section{Note:}

Series $1:$ Portland cement pastes with water (blue color).

Series 2 : Portland cement pastes with silica fume ( pink).

Series 3 : Portland cement pastes with fly ash (yellow).

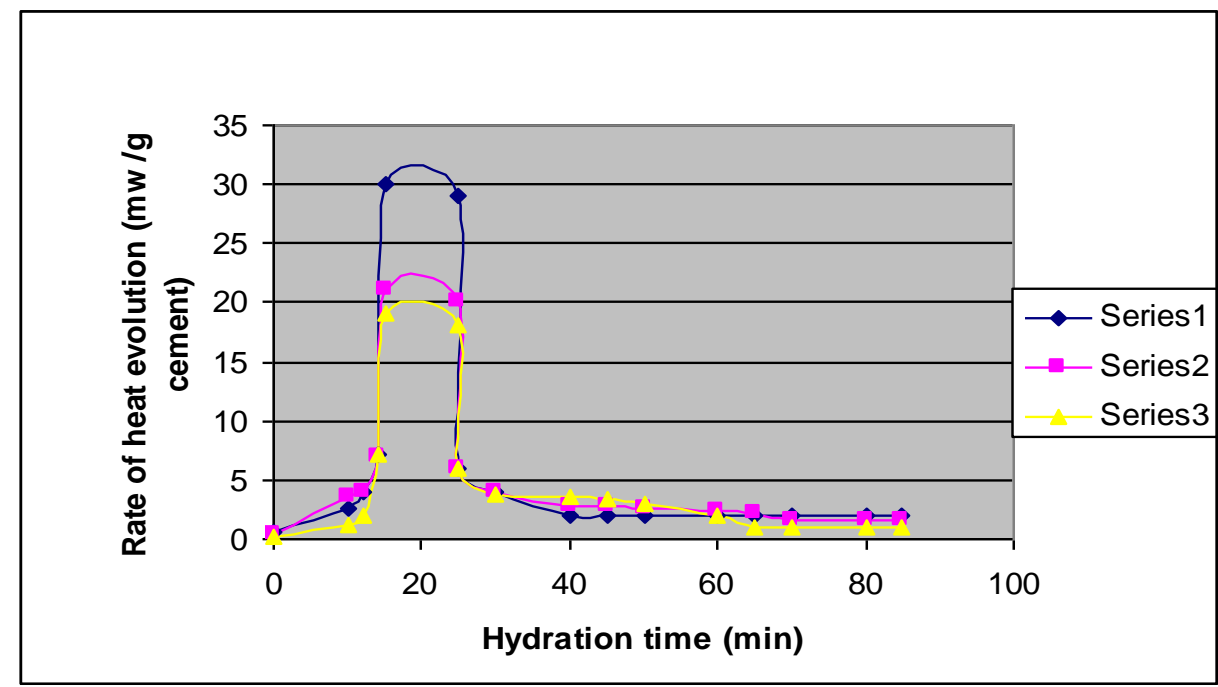

Fig1: Heat evolution of Yemeni cement pastes in the presence and absence of admixtures.

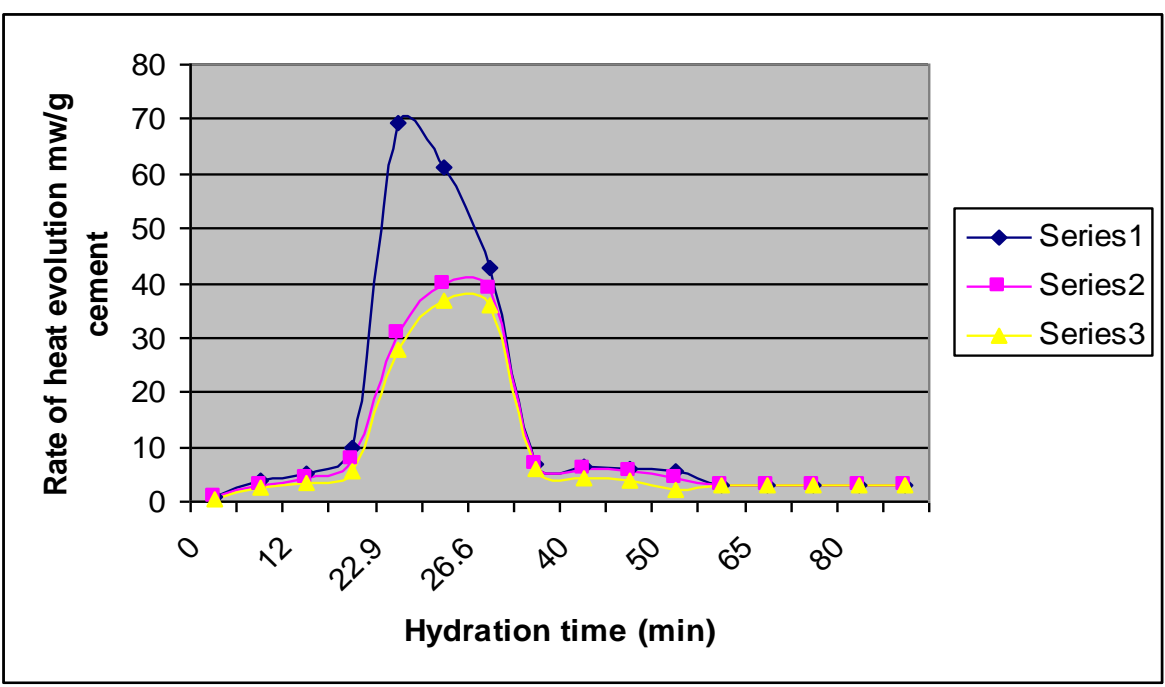

Fig 2: Heat evolution of Egyptian cement pastes in the presence and absence of admixtures. 


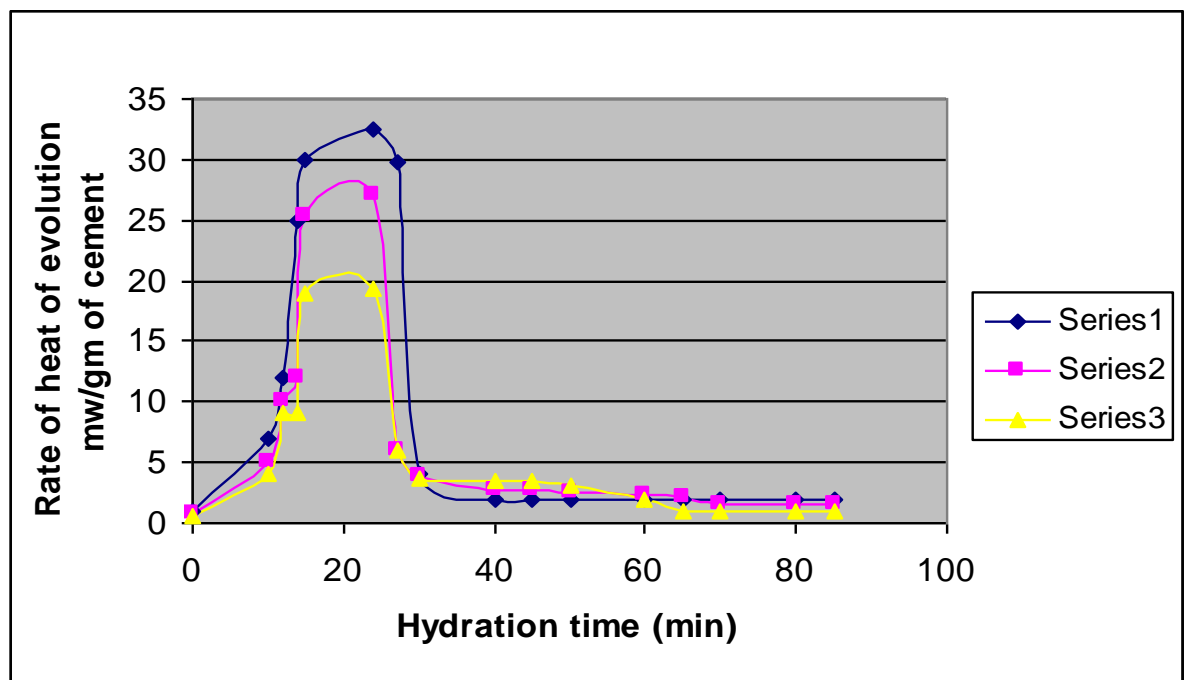

Fig 3 : Heat evolution of Saudi cement pastes in the presence and absence of admixtures

\section{4- CONCLUSIONS}

1- From the results following conclusions have been made.

Both the admixtures fly ash and silica fume retard the hydration of OPC.

2- For the same concentration (3.0 wt. (\%)) fly ash is better retarder than Silca fume and the retardation is due to adsorption on cement/ hydration products surfaces

3- All retarder have a longer induction period than ordinary Portland cement does. Calorimetric curves indicate that the higher the ratio of retarder in the mix, the lower the heat liberated at the beginning.

4- Indeed, size effect has a role on the retardation effect of a retarder and, liberated heat during hydration process of cement increases as the size of retarder decreases.

5- It can be concluded from the data reported in this paper and within the limits of the experimental conditions adopted that the additions studied resulted in the decrease of the portlandite content. Both the pozzolanic of silica fume and fly ash reaction that transforms the weak calcium hydroxide crystals into the strong calcium silicate hydrate gel, and the delay of hydration due to polymer addition appear to cause a decrease in the portlandite content, contributing to the improvement of the mortars' performance studied earlier by the authors.

\section{ACKNOWLEDGEMENTS}

The authors are thankful to Amran cement industry for providing us analysis of cement oxide composition, We are also grateful to petroleum cement which provide us the silca fume and fly ash oxide composition, we very thankful to physical chemistry research lab who help us to have these results 


\section{REFERENCES}

1) W.J.McCarter,P.N.Curran,Mag.concretes 84(1984)42-49.

2) S. Brunauer, P. H. Emmett and E. Teller, J. Am. Chem. Soc., 1938, 60, 309.

3) V.S.Ramachandran, concrete admixrures: Properties,Science and Technology, NOYES puplications, Park Kidge, NJ, USA, 1984.

4) A.Larvi,J.M.Bejen.Interaction of polymers with Portland cement during hydration: a study of the chemistry of the pore solution, Cem. Concr. Res., (1990) 139.

5) S.Chandra,P.Flodin,International of polymers and organic admixtures of

Portland cement hydration,Cem.Concr.Res.,17(1987)875

6) Harrison, T. A., Early-Age Thermal Crack Control in Concrete, Report 91, Construction Industry Research and Information Association, London, 1981.

7) (Correlation between Chemical Evolution and Thermophysical Properties of Cement Pastes): Influence of Temperature and Water/Binder Ratio).

8) P. Mounanga,C, S G. Bastian and A. KhelidjLaboratoire de Génie Civil de Nantes - Saint-Nazaire, I.U.T. de Saint-Nazaire, Saint-Nazaire, France.

9) N. E. Hager III and R. C. Domszy, J. Appl. Phys. 96, (2004) 5117-5128.

10) I.Aiad,S.Abd El-Aleem H.El.Diadamony,Cem.Concr.Res.32(2002)1839-1843.

11) E.E.Berry,R.T.Hemmings,W.S.Langley,G.G.Garette,Beneficiated fly ash: hydration,microstructure, and strength development in Portland cement, proceeding of the first International conference on fly ash, Silica Fume, Slag,and Natural Pozzolans in concrete,SP-114(1), Throndheim, Norway,1989,PP.241273.

12) Viveka Nand Dwivedia, Shiva Saran Dasa, Nakshatra Bahadur Singha*, Sarita Raib, Namdev Shriram Gajbhiyeb Materials Research, Vol. 11, No. 4, 2008 427-431.

13) Middendorf B, Singh NB. Poly (methacrylic acid) sodium salt interaction with hydrating Portland cement. In Proceedings 12th Int. Cong. Chem. Cem.; 2007; Montreal, Canada. p. 8-13.

14) Crow, R.D. and E.R. Dunstan. 1981. Properties of fly ash concrete. Effects of Fly Ash Incorporation in Cement and Concrete, Proceedings of Symposium N. Materials Research Society. 214-224.

15) Joshi, R.C., and R. P. Lohtia. 1997. Fly Ash in Concrete. Gordon and Breach Science Publishers.

16) Langan, B.W., K. Weng, and M.A. Ward.. Effect of silica fume and fly ash on heat of hydration of Portland cement. Cement and Concrete Research 32 (7) 2002: 1045-1051. 


\section{"تأثير المضافات على حرارة هلرتة الإسمنت المنتج في \\ اليمن ومصر والسعودية"}

لقد قمنا بدراسة حرارة الهرتة في ثلاثة أنواع من الإسمنت المنتج داخلياً في اليمن وخارجياً في مصر

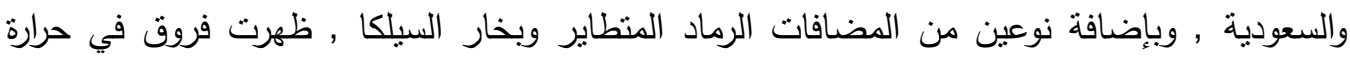
الهدرتة بين الثلاثة الأنواع , وجدت بأن المضافات تقلل من حرارة الهدرتة ولكن الرماد المنطاير أكثر

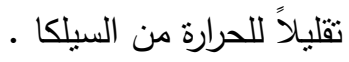

